\title{
A 100-Year Review: Lactating dairy cattle housing management ${ }^{1}$
}

\author{
J. M. Bewley, ${ }^{2}$ L. M. Robertson, and E. A. Eckelkamp \\ Department of Animal and Food Sciences, University of Kentucky, Lexington 40546
}

\begin{abstract}
Since the mid-1800s, farmers have been housing livestock. What began as a part-time solution for cold winters, stormy days, or injured animals has evolved into the main or only area in which cows spend their adult lives. With this change, farmers, academic researchers, and industry innovators have shaped the farm landscape, literally. Over the last 100 years, changes have been made for productivity, health, milk quality, reproduction, animal well-being, and farm profitability. We review a snapshot of those changes and look ahead to the future of lactating dairy cattle housing. All housing systems are moving toward improved cow comfort. Stalls in tiestall and freestall systems are now designed to accommodate cows based on body size and, in some cases, stage of lactation. Farmers may choose to build a compost bedded or traditional bedded-pack barn to maximize cattle rest or accommodate various breeds or sizes of cows. Looking to the future, external pressure and public perception may push farmers to consider other alternatives to total confinement. Future housing plans may include access to pasture or exercise lots, allowing cows to express their preferences for being outside or inside. Housing that allows natural expression of behavior while maintaining cow cleanliness and health may improve the lives of cows and farmers.
\end{abstract}

Key words: housing, management, lactating dairy cow, 100-year review

\section{INTRODUCTION}

Choosing the environment in which lactating dairy cows will spend most of their time is an important decision for dairy producers. This choice has considerable influence on productivity, health, milk quality, reproduction, animal well-being, and farm profitability. In the decision-making process, dairy producers must consider what system will work best for their respective

\footnotetext{
Received May 29, 2017.

Accepted August 22, 2017.

${ }^{1}$ This review is part of a special issue of the Journal of Dairy Science commissioned to celebrate 100 years of publishing (1917-2017).

${ }^{2}$ Corresponding author: jbewley@uky.edu
}

situations, given local climatic conditions, construction and building costs, labor availability, long-term maintenance and upkeep costs, and return on investment. Although pasture generally allows for excellent cow comfort, inclement weather and muddy conditions may present challenges related to cow cleanliness, milk quality, and heat or cold stress. These challenges have created the need for confinement housing. Traditionally, housing options for lactating dairy cows have consisted of conventional bedded-pack, tiestall, freestall, and compost bedded-pack barns. The early years of many peer-reviewed journals do not include information on dairy cattle housing. Early information on origins of housing types and initial building recommendations was collected from patents, extension publications, and some journal articles. We will describe the research of and advances in housing of dairy cattle in various systems over the last century (Appendix Table A1).

\section{CONVENTIONAL BEDDED-PACK BARNS}

Bedded-pack barns (BP), or straw yards, were a recognized form of loose housing facility by the mid1950s (Bickert and Light, 1982; Kammel, 2005). They consist of large resting areas of 5.6 to $9.3 \mathrm{~m}^{2}$ per animal (Bickert and Light, 1982; Thurgood et al., 2009), or 7.0 and $5.6 \mathrm{~m}^{2}$ per animal for large and small breeds, respectively (Kammel, 2005). Although BP easily accommodate different breeds and double as manure storage, they require intensive management and large amounts of bedding relative to tiestall or freestall housing to be effective (Bickert and Light, 1982; Thurgood et al., 2009; Benson, 2012).

A layer of gravel or concrete may be required as a base in the barn, depending on regulations, to prevent leaching of water laden with urine, manure, or other nutrients into the environment. Similar to other housing systems, good ventilation is necessary to ensure cow health, aid in pack drying, and reduce barn odor (Kammel, 2005; Benson, 2012). In a study of New York and Vermont dairies, Benson (2012) reported the following bedded-pack barn advantages: producer satisfaction, increased cow comfort, better manure storage, greater soil amendment values, and enhanced conservation practices. 
The reduced capital cost to build a BP compared with a freestall barn can make them an attractive option (Kammel, 2005). However, by the year after building erection, $1,549 \mathrm{~kg}$ of bedding per cow was required for adequate bedding of the pack area, increasing annual costs to maintain the barn (Benson, 2012). Similarly, Thurgood et al. (2009) noted an increase from $18 \mathrm{t}$ of bedding for the winter before moving into the bedded pack to $59 \mathrm{t}$ of bedding for the winter in years 1 and 2 of BP operation. This led to an annual amount of 391 $\mathrm{kg}$ /animal before moving into the bedded pack, 1,347 $\mathrm{kg}$ /animal in the first year of housing in the pack, and $2,910 \mathrm{~kg} /$ animal in the second year of housing in the pack. Thurgood et al. (2009) suggested that the increased bedding required and the high cost of bedding led to no overall economic benefit with the BP system. However, increasing capital cost for a greater space allowance (e.g., 9.3 instead of $7.0 \mathrm{~m}^{2}$ per animal) may reduce variable costs later through reduced bedding requirements. The higher surface area per cow increases the total water evaporated per cow, resulting in lower bedding requirements.

For cow cleanliness and health, dry bedding $(<15 \%$ moisture) should be used to maintain a clean environment and maintain low bacterial counts. Bedding requirements can range from 4.5 to $15.9 \mathrm{~kg} /$ cow per day (Kammel, 2005). Allen (2007) suggested a minimum of $7 \mathrm{~m}^{2}$ per cow with $18 \mathrm{~kg}$ of straw per cow per day to minimize environmental mastitis and maximize cow comfort. Bedding use may be reduced through removal of manure from the pack area or removing accumulated manure from feed alleys and water areas (Kammel, 2005; Thurgood et al., 2009).

\section{Health and Behavior}

Providing $10 \mathrm{~m}^{2}$ per cow instead of $9 \mathrm{~m}^{2}$ per cow improved lying time (Fregonesi and Leaver, 2002; Kammel, 2005; Fregonesi et al., 2009), increased SCC (Fregonesi and Leaver, 2001), and increased clinical mastitis incidence (Fregonesi and Leaver, 2001). Bedded-pack barns may lead to improved cow health and welfare compared with other housing systems. Less severe hoof disorders and reduced wear have been reported in BP-housed cows compared with cows in freestalls (Phillips and Schofield, 1994; Livesey et al., 1998; Webster, 2001).

\section{Hoof Health}

Livesey et al. (1998) noted that first-calf heifers housed on bedded packs versus those housed in freestalls with rubber mats and a straw layer experienced less severe claw horn lesions and less risk of developing white line and sole hemorrhages. Only heel erosion cases were more severe in BP-housed heifers, with heifers having thick, spongy heels that were "pitted" by heel erosion instead of worn down like the freestall-housed heifers. Neither system was the initial cause of claw horn lesions, but freestalls exacerbated claw horn lesion, white line hemorrhage, and sole hemorrhage severity (Livesey et al., 1998; Webster, 2001). Similarly, Phillips and Schofield (1994) reported that BP-housed cows exhibited deeper heels than those housed in freestalls. However, Phillips and Schofield (1994) and Livesey et al. (1998) reported no significant differences observed for lameness, with both housing systems maintaining a low change in locomotion score and no observed clinical lameness through the 6-mo study.

Somers et al. (2003) investigated causes of lameness in pasture herds, housed herds, and straw-bedded packs (BP) where cows were not housed on concrete. Mean percent of herds infected with interdigital dermatitis or heel erosion, digital dermatitis, and sole hemorrhages was lowest in BP compared with housed and pastured herds. Conversely, white line separation was greater in BP compared with housed and pastured herds (Somers et al., 2003).

\section{Lying Time}

Increased lying times have been reported in BP compared with freestalls (Kammel, 2005; Fregonesi et al., 2009). When $10 \mathrm{~m}^{2}$ of space was provided per cow, increased lying and rumination times were observed in BP relative to freestalls by Fregonesi and Leaver (2001). With $9.2 \mathrm{~m}^{2}$ per cow, no differences were noted in lying time, bed occupancy, and rumination time. High-yielding cows spent less time lying in straw BP, with no difference between high- and low-yielding cows in freestalls (Fregonesi and Leaver, 2002). When offered a choice between freestalls and BP, cows spent more time in BP and increased overall lying time. Phillips and Schofield (1994) noted that cows in all stages of the estrous cycle spent more time lying or feeding (interaction between housing and estrous period) and less time walking or standing in BP than in freestalls.

\section{Reproduction and Behavior}

Play behavior (mock fleeing, mock aggression, and environmental exploration) was noted when cows were moved from freestalls into the bedded pack, which may indicate greater animal welfare benefits (Fregonesi and Leaver, 2001). More estrous behaviors were recorded in bedded pack barns compared with freestall barns, including standing to be mounted, mounting without standing, successful mounting, chin rubbing on rump, sniffing or licking of the genital area, and fewer unsuc- 
cessful mounting attempts. Consequently, pregnancy rate at first service improved in $\mathrm{BP}$ compared with freestalls (Phillips and Schofield, 1994).

\section{Disadvantages}

Some disadvantages have been associated with BP. The amount of bedding needed and the potential cost of bedding were greater in $\mathrm{BP}$ compared with freestalls (Kammel, 2005; Allen, 2007). However, Buli et al. (2010) suggested using 20 to $25 \mathrm{~kg}$ of sand per cow per day in the United States and 5 to $8 \mathrm{~kg}$ of sand per cow per day in Europe in freestall barns, similar to the amount of bedding required in bedded packs. Although milk yield did not change, Phillips and Schofield (1994) reported that cows decreased in body condition in straw-bedded pack barns compared with freestall barns. Consumption of bedding straw by cows when in the pack area could have increased rumen fill with a low energy source.

Barn orientation and space per animal are important in maintaining hygiene score and avoiding detrimental effect in straw-bedded packs (Fregonesi and Leaver, 2001, 2002; Kammel, 2005). Cows housed in straw-bedded packs with low space allowance produced increased SCC, clinical mastitis incidence, and hygiene scores with an accompanying milk yield reduction (Fregonesi and Leaver, 2001). This may be because of greater environmental pathogen exposure in bedded-pack barns (Kammel, 2005). Additionally, Kammel (2005) noted that access from the short side of the barn instead of the long side of the barn decreased space efficiency and cleanliness of the entryway.

\section{TIESTALL BARNS}

Tiestall or stanchion barns were the traditional type of dairy housing for many years, and stayed the most popular type of housing until the advent of larger herds and other dairy industry changes in the 20th century.

In 1850, the first US patent for a stanchion barn was awarded. Before 1900, the stanchion referred to a stall fitted within a barn designed to house a variety of animals. Stanchions were not intended to house the animals in total confinement but instead were seasonal housing during winter and year-round during milking (Hatch, 1850). Throughout the end of the 19th century, varied designs for stanchions were patented. The debate of optimum housing type dates to this period with tie chains, chainless gated stalls, and headlock-type devices all considered in stanchion stall design. (Huse, 1880; Gibbs, 1887; McCartney, 1887). In 1897, the first US patent for a type of tiestall housing was awarded. This tiestall consisted only of a divider, attached to the floor, in which feed was on one side and the cow on the other. The tie chain was fastened to this floor-level piece of either wood or metal (Witt, 1897). The tiestall is distinct from the previous patents for stanchions, as "tiestall" referred to a stall to go in a barn designed specifically to house only dairy animals. Before 1900, cows were housed with other animals in multipurpose barns, often containing tiestalls to house dairy cattle alongside other various livestock.

After the turn of the century, cows were still rarely housed in total confinement; however, these dairycattle-only stalls paved the way for a total confinement option. In 1911, the design for a tiestall was improved upon by M. S. Batchelder through the addition of a trough, dividing wall, and a device to prevent cows from stepping into or lying in the gutter (Batchelder, 1911). By 1930, a design for a tiestall had been patented that was very similar to the basic design that is seen today, with tubular metal stall dividers, concrete floors, curbs, and manure gutters (Hibbs and Miller, 1932).

\section{Stall Design}

Some studies attribute the decrease in cow comfort in freestall herds to the size of the stalls. The same consideration applies to tiestalls. In a study by Tucker et al. (2004), cows in wider stalls $(126 \mathrm{~cm})$ spent more time lying down (10.8 vs. $9.6 \mathrm{~h} / \mathrm{d})$ and less time standing with only the front hooves in stalls (58 vs. $85 \mathrm{~min} / \mathrm{d}$ ) compared with cows in narrower stalls $(106 \mathrm{~cm})$. Stall size is vital to the success of a tiestall system because cows do not have a stall size choice. The Ontario Ministry of Agriculture suggests that tiestall barns should accommodate the needs of cows in various life stages, and therefore body sizes, by having 3 different stall types: for first lactation, milking, and dry cows (Anderson, 2014).

Another consideration in tiestall barns is the ability of the cows to lunge forward naturally when rising to the standing position. Cows need 76 to $112 \mathrm{~cm}$ of forward lunge space ahead of where the front knees are during resting position. The neck rail height should be at least $15 \mathrm{~cm}$ above the stall surface and provide 81 $\mathrm{cm}$ of vertical clearance. In 1964, a modification to the tiestall was patented, which included a tie that allowed for forward lunging with the lack of a board in front of the cow (Berg, 1964). This addition has been widely adopted and improved upon to include ties that do not have any forward rails, only rubber-covered chains that prevent injury and allow for more free forward movement.

In a study by Zurbrigg et al. (2005), the height of the tie rail, another indicator of proper lunging space, 
was correlated with neck lesions and udder cleanliness. Farms with high tie-rails (116 to $132 \mathrm{~cm}$ ) had $70 \%$ fewer neck lesions compared with mid-range tie-rail height (99 to $114 \mathrm{~cm}$ ). In addition, for every $2.5-\mathrm{cm}$ increase in tie rail height, the prevalence of clean udders increased $0.2 \%$ (Zurbrigg et al., 2005). Tiestall rails have been improved to include options with and without stall dividers, water bowl attachments, feed bunk dividers, various types of neck rails, and different points of chain attachment.

In 2009, stall dividers made of flexible plastic were patented. Several companies patented their own version of the flexible stall parturition between 2009 and 2013 . Flexible stall dividers could provide an advantage in cow comfort in tiestall and in freestall facilities through reducing cow injuries from stall dividers (Cow-Welfare, 2017). Gutters for waste removal have also been adapted over time. In 1890, W. H. Brewer patented a stall with a slatted floor at the rear and a gutter behind that to facilitate easier waste removal. Prior to the advent of the gutter system, "it was customary to clean the stable floor thoroughly before milking" (Brewer, 1890).

\section{Barn Design}

Equally as important as the stall is the barn in which the stalls are housed. Because tiestall facilities are often total confinement systems, factors such as ventilation and manure management become vital. Ventilation has improved significantly in recent years for all dairy housing systems. Ventilation for tiestalls can be both natural and mechanical. Natural ventilation relies upon thermal buoyancy, or the temperature difference inside and outside of the barn, and air exchange driven by wind. Natural ventilation relies on inlets at the eaves or inlets in the sidewalls of the barn for airflow in and ventilation stacks along the roof for airflow out. Pennsylvania State recommendations for types of natural ventilation systems in existing facilities specify local airspeed, orientation and placement of the barn, roof slope, and the size and placement of the openings (Graves, 2017). Mechanical ventilation in tiestall barns can include tunnel ventilation and other fan-based systems. Tunnel ventilation is a special system designed only for summer warm weather conditions. Tunnel ventilation is optimized for a 2-row tiestall barn with more than 40 cows. It relies upon large fans in the end of a barn and large outlet spaces with exhaust fans in the other end. Tunnel ventilation is preferred in weather that could cause heat stress conditions due to the high-speed airflow provided (Tyson et al., 2014). Other types of mechanical ventilation installations include the use of fans and inlets to promote airflow. Selection of fans and inlets is based upon the consideration of static pressure, airflow, and efficiency. Pennsylvania State recommends a combination of these types based on specific farm considerations (Graves, 2015).

\section{Technology}

Technology available to complement tiestalls has also been invented. One notable technology is the addition of individual automatic waterers available to each cow or every other cow. In 1932, a patent for a tiestall design included a place for such a water bowl, stating that they were common in "modern" dairy barns at the time (Hibbs and Miller, 1932).

Another technology created specifically for tiestalls is trainers. Trainers teach cows to step back when arching their back to defecate or urinate to encourage manure in the gutter and improve stall cleanliness (Anderson, 2008b). The first patent for a tiestall trainer was in 1930 (Jost, 1930) and it functioned as a spring-loaded whip. The first electric version was patented in 1966 (Treangen, 1966) and improved upon to the type in use today (Rousseau, Desjardins, and Rousseau, 1999). Research has shown that stalls are no dirtier with the use of the trainer $2 \mathrm{~d}$ per week than $7 \mathrm{~d}$ per week, and that $90 \%$ of shocks received from the trainer do not happen during defecation (Anderson, 2008b).

\section{Tiestall Milking}

In many tiestall barns, the milk pipeline runs throughout the barn and the milk machine itself is mobile and travels to each stall. This is a stark contrast to the freestall system, which requires moving the cows for each milking and the building of a holding pen facility. Tiestall milking brings many advantages, including the individual attention given to each cow, and the producer does not need to build additional milking facilities. The design of this system has greatly evolved over the past 100 years as milking technology in general has changed. The first milking machine was built in 1875 , and was simply a catheter inserted into the teat to promote milk letdown. The first modern milking machine, the pulsating milker, was patented in 1893 by Dr. Alexander Sheils (Sheils, 1894). The entire milking machine, including all of the lines and the milking can, had to be moved to each cow in a tiestall system. In the modern pipeline system, there is a vacuum and milk pipeline outlet at each tiestall, and only the milking apparatus is moved from stall to stall. The cow is milked and all milk is transported via the pipeline system in the barn to the bulk tank. 


\section{Cow Health}

Housing in tiestall barns reduces the stress from constantly shifting social orders and has been shown, in some studies, to reduce mortality rates compared with freestall facilities. Dechow et al. (2011) reported that cows in tiestall barns had lower mortality and earlylactation cull rate than cows housed in freestall barns, but both tiestall and freestall herds had higher mortality than bedded-pack facilities.

However, tiestalls present issues in cow comfort and adequate exercise. Cows housed in tiestalls are more prone to lameness and sole disorders than cattle housed in loose housing (Bielfeldt et al., 2005). Konggaard (1977) stated that dairy cattle housed in tiestall barns had reduced reproductive performance and higher cull rate $(23 \%$ for tiestall herd, $18 \%$ for freestall, and $15 \%$ for loose housing) because of reproductive failures compared with cows in freestall and loose housing systems over 4 yr. In total, 69 cows were confirmed pregnant over the 4-yr period in tiestall housing, compared with 81 in freestall cubicles and 86 in deep-bedded loose housing. A mean of 2.33 inseminations was required to impregnate cows in a tiestall barn, compared with 2.32 in a freestall and 1.96 in loose housing facilities.

\section{FREESTALL BARNS}

Freestall housing facilities have been in use since the 1960s. Adolph Oien developed the first barn identified as freestall in 1959, in Washington State, in which individual stalls were installed in an existing loose housing shed. The primary driver identified was a lower bedding requirement per cow while maintaining clean animals. Later advantages included easy separation of lactating cow groups (by days in milk, parity, and health status) and feeding of a TMR (Bickert and Light, 1982).

\section{Barn Design}

Two early freestall types were developed: a U-shaped and an L-shaped system. The U-shaped system consisted of resting and feeding areas that formed legs of the U, with the milking parlor forming the base. This resulted in a large amount of paved area that needed to be scraped. The development of L-shaped barns reduced the amount of paved area. These barns were generally oriented with a south-facing resting area, an east-facing feeding area, and the milking parlor at the system apex. The importance of paved area space per cow was downgraded after 1962. In 1962, Paul Varney (in Turner, Maine) used an inventive freestall design on his farm. This design, built by Rodney Martin, integrated feeding and resting areas, albeit still sepa- rated, under a single roof. This barn adhered to the prior recommendation of $9.3 \mathrm{~m}^{2}$ of paved area per cow with 13 to $15 \mathrm{~m}^{2}$ of total area provided per cow. After adoption of this style, stall design - not paved area per cow-was reported to be a predictor of cow cleanliness. Consequently, the recommended paved space per cow was reduced to $7.4 \mathrm{~m}^{2}$ (Bickert and Light, 1982).

In 1975, modified environment housing styles were introduced. Cold housing systems were not fully enclosed and had internal temperatures similar to ambient temperatures, whereas completely enclosed housing kept the internal temperature higher than ambient. The modified freestalls attempted to keep animals warmer in winter than in cold housing but not as warm as in completely enclosed barns. These barns relied upon natural ventilation for temperature and moisture control. Covered barns with a modified environment were particularly advantageous for reducing frozen manure in alleyways and controlling snow and rain runoff. An additional freestall design was the corral style; in this barn design, only the freestall area was covered, with or without a cover over the concrete feed alley and bunk, generally with an adjoining dirt lot (Bickert and Light, 1982).

More recently, the design of individual stalls has been standardized by animal weight range. The areas of design concern are body space, head space, and lunge space (Bickert et al., 2000). Body space defines the area from the front of the cow's knees to her rear, head space is the area in front of the cow's body occupied by her head, and lunge space is the additional space required for the cow to thrust her head when lunging forward to rise. The 2 main types of freestall designs are forward lunge and side lunge. A forward lunge provides longer stalls to allow animals to move forward to propel themselves up, whereas side lunge allows animals to move their heads into adjacent stalls and lunge sideways to stand. Side lunge freestalls allow the animal to place their heads above or below the lower partition (Bickert et al., 2000). Lunge space is the forward space required when lying down or rising up. The bob zone is the area within the lunge space where the chin nearly touches the ground when rising. When head lunge space is downward and upward, lunge space extends forward. Standing requires space vertically and forward, whereas hindquarters require space laterally (Buli et al., 2010).

Stalls consist of side partitions defining each cow's individual area, a brisket board to define their total lying area, a neck rail to prevent the animal from standing too far forward in stalls, and a base for the animal to rest on. The brisket board and neck rail limit the cow's lying and standing area, respectively, to prevent manure and urine from filling the rear end of the stall. Brisket boards and neck rails may be placed too far 
forward, allowing manure and urine to enter the stall's rear. Shorter stalls, or brisket boards placed too far to the rear, limit the resting area for cows and may inhibit comfort when the cow is resting (Bickert et al., 2000). Brisket boards, particularly wooden boards, may reduce stall usage. In a Canadian study, lying time and length of lying bout were shorter when brisket boards were present in stalls than when they were absent (Tucker et al., 2006). Tucker et al. (2006) suggested that contact with stall features was uncomfortable for resting animals, decreasing the length of lying bouts. This change may be less severe with softer, more rounded, or lower brisket boards than the wooden ones used in the $\mathrm{Ca}$ nadian study.

Neck rails define the stall standing space and alter the time spent standing in a stall. When the neck rail is absent, more time is spent standing; and when the neck rail height is lower, standing time decreases. Changes in neck rail height did not alter time spent lying or the amount of defecation or urination in the stall (Tucker et al., 2005). Stalls are generally raised above the concrete alleyway, resulting in a curb $(15-20 \mathrm{~cm})$. A curb permits cows to avoid resting in manure or slurry and prevents manure or slurry from entering the stall during alley scraping or flushing (Bickert et al., 2000).

If a mattress or pad is used as the bedding surface, additional bedding material may be added to improve stall comfort, reduce injury potential, add resilience, absorb moisture, and collect manure tracked into the stall. Mattresses consist of a filler in a heavyweight polypropylene or other heavy fabric material (Bickert et al., 2000). Shredded rubber, water, and gel have been used as filler for mattresses (Bickert et al., 2000; Fulwider et al., 2007; Main, 2013). Pads can be rubber mats, plastic mats, carpeting materials, or other compressed products. Compressed earth or a concrete base may be the sole resting surface. However, compressed earth allows deep pockets to form at the front and rear of the stalls. These pockets trap manure and urine and increase the cow's difficulty in standing and lying. Pads, compressed earth, and concrete resting areas are not satisfactory for cushioning and require the addition of larger amounts of bedding to keep cows comfortable.

In a deep-bedding system, at least $15 \mathrm{~cm}$ of bedding depth should be provided (Bickert et al., 2000). Bedding choices include sawdust, straw, wood chips, shredded newspaper, composted or dried separated manure solids, corn stalks, bark, sunflower hulls, rice hulls, peanut hulls, sand, and ground limestone (Hogan et al., 1989, Bickert et al., 2000; NYSCHAP, 2002). Bickert et al. (2000) suggested twice-daily maintenance to remove wet bedding and manure, and the addition of bedding once or twice a week. Alleyways in all housing systems need to be scraped or flushed clean a minimum of twice a day (Bickert et al., 2000).

\section{Hygiene}

Hygiene depends on the bedding material used, management style, barn design, and stall dimensions. Different areas of the barn affect hygiene on different parts of the cow. Generally, bedding surface and bedding type have more influence on udder hygiene. Scraping frequency, ease of movement, and manure management system have more influence on leg hygiene (Schreiner and Ruegg, 2003).

Cows housed in sand freestalls had a greater proportion of higher hygiene scores than cows housed on mattresses or waterbeds (Fulwider et al., 2007). However, cows housed in sand freestalls were cleaner than cows housed in straw-bedded freestalls (Norring et al., 2008). Three main areas showed significant differences between straw and sand: mid-legs, upper legs, and belly. Conversely, van Gastelen et al. (2011) reported no differences in cow cleanliness for the udder, leg, flank, or total rear body score when animals were housed in freestalls using box compost, horse manure, sand, or foam mattresses, respectively, as a stall base.

\section{Inorganic Bedding}

Inorganic materials, namely sand, have been considered the gold standard for deep-bedded freestalls (Bickert, 1999; Allen, 2007). Sand can be sourced from a variety of locations: mason sand, dredged sand, beach sand, or quarried sand (Stowell and Inglis, 2000; Buli et al., 2010). Sand has 5 main qualities that make it an ideal bedding source: (1) it provides a comfortable resting surface, improving cow comfort; (2) it limits bacterial growth; (3) it has a low initial moisture content, reducing moisture build-up; (4) it remains cool and reduces heat stress through lower lying temperature than other bedding materials; and (5) it reduces slipping through improved traction (Stowell and Inglis, 2000; Allen, 2007; Buli et al., 2010). The nature of loose sand allows for movement with the animal, reducing friction on the hocks and increasing cushion for the animal (Bickert, 1999). A top layer of sand dries quickly due to water binding to single grains of sand, limiting both growth and survivability of bacteria (Stowell and Inglis, 2000; Allen, 2007; Buli et al., 2010). Sand has a lower environmental impact than other bedding types because of its natural and reusable nature (Buli et al., 2010). Increased traction allows cows to express natural behaviors (mounting) with less risk of slipping (Anderson, 2008a). A film of sand in alleyways increased 
hoof growth and wear due to a more abrasive surface, particularly when concrete flooring was present (Vokey et al., 2001). Vokey et al. (2001) suggested that a rubber alley in conjunction with concrete or sand stalls balanced hind claw growth and wear, whereas concrete alleys with mattress stalls caused imbalances in wear and growth in both lateral and medial hind claws.

Large quantities of sand are required per cow per day (Buli et al., 2010). A stall base of sand requires 15 to 20 $\mathrm{cm}$, although a minimum of $25 \mathrm{~cm}$ has been suggested, with complete sand bedding replacement necessary every 12 to 14 d (Bickert, 1999; Buli et al., 2010; Cook, 2010). Additional bedding may be needed during the week to cover the curb, and the stall should be cleaned twice daily (Allen, 2007; Buli et al., 2010). The amount of bedding used will change with the sand level relative to the curb. If sand is above the curb, 20 to 25 $\mathrm{kg} / \mathrm{d}$ may be kicked out, instead of 10 to $15 \mathrm{~kg} / \mathrm{d}$ when the level is below the curb. Failure to replace sand can decrease sand usage, but it will also decrease effective resting space and lead to decreased stall usage (Buli et al., 2010). Fulwider et al. (2007) noted that short sand lying areas and stalls that were not maintained at or above the curb often resulted in greater incidence of hock lesions. This could be due to abrasions from the exposed concrete curb. Recycled sand caused more knee injuries than fresh sand (Fulwider et al., 2007).

Bickert (1999) claimed that sand's only detriment was its handling difficulty in manure management. Similarly, Rodenburg (2000) referred to sand as the most laborious bedding option due to its difficult handling. These difficulties are expressed through increased wear on equipment and difficulty in slurry management (Buli et al., 2010).

\section{Organic Bedding}

Organic materials have been used extensively as bedding material, both as a top dressing for mattresses or pads and in deep-bedded stalls. Allen (2007) advised a minimum of $3 \mathrm{~kg}$ per cow per day of sawdust and 5 $\mathrm{kg}$ per cow per day of straw as top dressing for mattresses, waterbeds, or gel mattresses. Kiln-dried bedding wood sources undergo a drying process that kills most bacteria. Because of this, kiln-dried bedding is often recommended for freestall and compost beddedpack barns (Janni et al., 2006; Allen, 2007). Green bedding materials are from wood sources that have not undergone a drying process (Briggs, 1994). The greatest physical difference between green and dried wood sources is their moisture content, with kiln-dried bedding being able to absorb more moisture than green bedding (Briggs, 1994; LeBlanc and Anderson, 2013).
Although Newman and Kowalski (1973) inferred that green bedding materials sustained higher bacterial counts, specifically Klebsiella pneumoniae, green sawdust was only compared against sand bedding. Fairchild et al. (1982) compared several bedding materials and teat swabs for total counts of coliforms and Klebsiella spp. One trial compared bedding and teat-end bacterial counts in stalls bedded with either green softwood sawdust or the same sawdust mixed with agricultural lime. No differences were found for total coliform or Klebsiella counts between the 2 bedding types for the trial duration. There appeared to be little benefit of mixing lime into sawdust in the rear of freestall, as the increase in Klebsiella spp. was numerically small and the $\mathrm{pH}$ of both beddings fell within a range of 6 to 8 , compatible with coliform growth. When green sawdust was compared strictly with bedding with agricultural lime, lower growth of total coliforms and Klebsiella spp. was reported for lime bedding and teat ends.

Fairchild et al. (1982) compared total coliforms and Klebsiella spp. counts for green softwood sawdust, washed concrete-grade sand, agricultural lime, and cellulose fiber from old newspaper. Total coliform counts were higher in sawdust and newspaper than in sand and lime. Similarly, Klebsiella spp. counts were higher in sawdust and newspaper than in sand and lime. In both studies, lime and sand exhibited a $\mathrm{pH}$ outside the acceptable growth range for coliforms and offered a lack of nutrients and moisture (Fairchild et al., 1982). Total coliform and Klebsiella spp. in "fresh" sawdust bedding counts were generally higher than those in stockpiled bedding (Fairchild et al., 1982). Fairchild et al. (1982) suggested that high bacterial populations did not definitively lead to udder infection under good management conditions, as no cases of clinical mastitis were reported.

\section{COMPOST BEDDED-PACK BARNS}

Compost bedded-pack barns (CBP) have become a housing system of interest globally. In the United States, the first CBP were developed by Virginia dairy producers in the 1980s to increase cow comfort and longevity (Wagner, 2002). Minnesota (Janni et al., 2006; Barberg et al., 2007a; Shane et al., 2010), Kentucky (Damasceno, 2012; Black et al., 2014; Eckelkamp et al., 2014), Ohio (Douridas, 2012; Zhao et al., 2012), and New York (Petzen et al., 2009) researchers have examined CBP and herds housed within them. Israel, Germany, Austria, the Netherlands, South Korea, Italy, and Canada have begun using CBP as housing systems (Ferrari and Moscatelli, 2009; Galama, 2011; LeBlanc and Anderson, 2013). South Korea, Brazil, Argentina, 
and Columbia have also recently adopted the system (J. L. Taraba, University of Kentucky, Lexington, personal communication; Albino et al., 2017).

\section{Barn Design}

Compost bedded-pack barns may be a more sustainable system than traditional dairy housing facilities. As a loose housing system, a CBP does not include the stalls and partitions found in freestall housing. Without stalls, the cows' resting and exercise areas are combined (Barberg et al., 2007a; Galama, 2011; Black et al., 2013). This combination of resting and exercise space for animals concurrently reduces greenhouse gas emissions and cost compared with freestall barns, and maintains cow health and well-being (Galama, 2011). The large, open resting areas ( 7 to $30 \mathrm{~m}^{2}$ per cow) are generally separated from a concrete feed alley by a 1.2-m-high retaining wall (Janni et al., 2006; Klaas et al., 2010; Black et al., 2013). If space per cow decreased below $9.3 \mathrm{~m}^{3}$, compaction and moisture could increase, inhibiting compost efficacy (Janni et al., 2006).

To allow easy access to the feed alley and water, walkways onto the pack should be provided every 35 to $40 \mathrm{~m}$ (Janni et al., 2006). Feed bunk space per cow should be 46 to $76 \mathrm{~cm}$ (Janni et al., 2006; Bewley et al., 2013) with at least 2 water troughs in the feed alley. Water troughs should be separated from the pack by a retaining wall to decrease moisture on the pack $(0.91$ $\mathrm{m}$ of water space per 15 to 20 cows; Janni et al., 2006; Bewley et al., 2013).

To maintain adequate natural ventilation and offset the height of the retaining wall, high sidewalls (4 to $5 \mathrm{~m}$ ) are required in the barn (Janni et al., 2006; Bewley et al., 2013). Further requirements to maintain adequate natural ventilation include a roof pitch of at least 4:12, ridge vent opening of at least $7.6 \mathrm{~cm}$ for every $3.0 \mathrm{~m}$ of roof width with a minimum opening width of $30.5 \mathrm{~cm}$, and an east-west orientation (Bewley et al., 2013). To prevent excess moisture from entering the pack, roof overhangs should be no less than $1 \mathrm{~m}$ and preferably a length one-third the height of the sidewall opening (Janni et al., 2006; Bewley et al., 2013). A base of clay, gravel, or concrete may be required to prevent leaching of urine, slurry, or other nutrients into the environment, depending on current government restrictions (Bewley et al., 2013). Additional lighting or mechanical ventilation may be used in the barns, depending on dairy management style (Janni et al., 2006; Damasceno, 2012). Fan speeds of $9.6 \mathrm{~km} / \mathrm{h}$ may increase the length of time bedding will last in a barn, decreasing bedding costs by $\$ 11,800$ per year (Eckelkamp, 2014). Any features in the barn need to be high enough to allow tractors entry onto the pack regardless of bedding depth for normal tilling and maintenance (Janni et al., 2006).

Composting the pack area allows feces and urine to be handled as solids (Janni et al., 2006). Barns can store manure for 6 to 12 mo before cleaning is required. The solid portion is commonly used for direct land application in the fall, although one-half to two-thirds could be removed in spring to allow adequate summer storage. This allows reestablishment of the barn before cold weather starts (Janni et al., 2006). The concrete feed alley collects 25 to $30 \%$ of manure and urine produced. This slurry needs to be handled and stored in a manure handling facility such as a lagoon, mini-manure pit, or stack slabs, or with daily manure hauling (Janni et al., 2006; Barberg et al., 2007a). Manure from the feed alley should not be spread back onto the pack, as the microbial activity of drying should equal the amount of manure voided on the pack. If the manure is spread onto the pack, it may increase the amount of bedding needed and create wet spots or overly manure-laden areas if not evenly spread. In addition, the extra traffic (from tractor or spreader) may increase compaction and reduce compost activity through reduced aeration (Janni et al., 2006).

\section{Pack Management}

Compost bedded-pack barns require periodic bedding addition and twice-daily tilling (Janni et al., 2006; Barberg et al., 2007a; Black et al., 2013). Aeration (tilling) incorporates manure and air (oxygen) into the pack (Shane et al., 2010). This process promotes aerobic microbiological activity, heating and drying the pack. Tilling of the pack also exposes greater pack surface area for drying (Janni et al., 2006). Heating and drying the pack provides a fresh, dry surface for cattle to lie on (Shane et al., 2010). Ideally, the internal temperature for CPB at a depth of 15 to $31 \mathrm{~cm}$ ranges from 43.3 to $65.0^{\circ} \mathrm{C}$ (Janni et al., 2006; Bewley et al., 2013). Areas of the barn that are chunky and compacted after stirring indicate pockets of anaerobic activity and lower temperature (Janni et al., 2006). The depth of tilling varies by individual producer and the specific tillage tool used (18 to $30 \mathrm{~cm}$; Janni et al., 2006; Barberg et al., 2007a). Unlike US CBP, Israeli and Denmark compost barns are only tilled once per day (Klaas et al., 2010; Bjerg and Klaas, 2014). However, some US producers chose to till once or 3 times per day, depending on management style (Black et al., 2014).

To start a CBP, a bedding layer from 25 to $50 \mathrm{~cm}$ deep is added (Janni et al., 2006; Barberg et al., 2007a; Black et al., 2013). In Kentucky, producers began these barns with $25 \mathrm{~cm}$ of shavings. Bedding material is 
added to the pack at a mean layer of $8.8 \mathrm{~cm}$ over the entire barn area $\left(\mathrm{m}^{2}\right)$, ranging from a dusting of bedding to a full load of bedding (Black et al., 2013). The influx of moisture in CBP comes from feces, urine, and moisture from microbial activity (Janni et al., 2006). In Minnesota, a full semi-load (14 to 16 t) is added when moisture content enables bedding to stick to cattle (every 1 to 5 wk; Janni et al., 2006; Barberg et al., 2007b; Endres and Janni, 2007). Israeli researchers did not add additional bedding in their CBP, instead relying solely on the composting process to maintain dry bedding (Klaas et al., 2010). Bewley et al. (2013) recommended a moisture range of 40 to $60 \%$ before adding new bedding. Shane et al. (2010) recommended keeping moisture content in the top $15 \mathrm{~cm}$ of the pack below $65 \%$. More recently, $55 \%$ moisture was suggested as the benchmark for adding new bedding (Bewley et al., 2012; Eckelkamp et al., 2016b).

\section{Bedding Material}

Several different types of bedding have been used in CBP. Janni et al. (2006) and Barberg et al. (2007a) recommended sawdust and dry, fine wood shavings, although ground soybean straw was also effective. Kentucky dairy producers used green and kiln-dried shavings or sawdust, a mixture of shavings and sawdust, a mixture of soy hulls and shavings, or a mixture of soy hulls and sawdust (Black et al., 2013). Shavings have the potential to improve handling, mixing, aeration, and biological activity due to their large surface area (Janni et al., 2006). This increases the ability of microbial populations to grow and break down manure and urine added but prevents excessive compaction of the bedding between tillings (Janni et al., 2006).

Farmers in Israel and the Netherlands have used dried manure or compost from other sources (food or paper industry waste) in compost barns (Klaas et al., 2010; Galama, 2011). Bjerg and Klaas (2014) reported that in Denmark, CBP were bedded with wood chips with leaves, roots, and garden residuals, a combination of sawdust and wood shavings, or heathland vegetation. Israeli CBP established composting using layers of an inorganic residual product from oil extraction (similar to cat litter), paper industry waste, or a layer of dried manure obtained before establishment of the compost system. However, only the barn that used dried manure achieved a heat greater than ambient temperature (Klaas et al., 2010).

Some bedding materials are unsuitable for CBP. Coarse hay and cereal grain straw matted and clumped, decreasing effectiveness as bedding material. Corn stover does not maintain a coarse particle size, decreasing air incorporation into the pack (Petzen et al., 2009). Wallboard (92\% calcium sulfate, $7 \%$ paper, and $<1 \%$ impurities or additives) did not promote heat production (LeBlanc and Anderson, 2013). Janni et al. (2006) did not recommend straw, corn stalks, and wet or green sawdust. Straw and corn stalks proved difficult for proper tilling using the various tillage tools. Wet or green sawdust decreased the amount of water that could be absorbed from the pack (Janni et al., 2006). The increased possibility of Klebsiella spp. counts in bedding also increased concerns regarding green sawdust (Newman and Kowalski, 1973; Janni et al., 2006; Bewley et al., 2013). Cedar, black walnut, and cherry were not recommended for CBP bedding because of antimicrobial properties or the potential to cause diseases such as laminitis (Janni et al., 2006; Bewley et al., 2013).

\section{Bedding Bacteria and Cow Health}

Early CBP research suggested that maintaining a temperature of 54 to $65^{\circ} \mathrm{C}$ for 3 to $4 \mathrm{~d}$ had the potential to inactivate pathogens and viruses, destroy weed seeds and fly larvae, and decrease odor emanating from the pack. Inactivating mastitis pathogens was of particular interest (Janni et al., 2006). However, research by Black et al. (2014), Barberg et al. (2007a), Eckelkamp et al. (2016b), and Petzen et al. (2009) indicated that managing for good composting allowed proliferation of coliforms, staphylococci, streptococci, and bacilli species in the pack. Although bacterial levels were high, the expected effects on SCC, bulk tank SCC, and clinical mastitis have not been seen (Barberg et al., 2007b; Black et al., 2014; Eckelkamp et al., 2016a).

After transitioning to $\mathrm{CBP}$, Minnesota dairy producers reported SCC to be $325,000 \pm 172,000$ cells $/ \mathrm{mL}$, below the state average of 357,000 cells/mL (Barberg et al., 2007b). The average prevalence of mastitis infection decreased after moving into the CBP from previous housing facilities (Barberg et al., 2007b). When comparing well-managed CBP against well-managed sand freestall barns, no differences were found between SCC, clinical mastitis incidence, or bulk tank SCC (Eckelkamp et al., 2016a).

Hygiene scores for cows housed on compost barns were similar to those housed on waterbeds in freestalls and lower than those for cows housed in sand freestalls or rubber-filled mattresses (Fulwider et al., 2007). Eckelkamp et al. (2016a) also reported no difference between CBP and sand-bedded freestall barns. Conversely, Lobeck et al. (2011) found that animals housed in CBP exhibited greater overall hygiene scores than animals in sand-bedded cross-ventilated and naturally ventilated freestall barns. 
Hock scores were lower or nonexistent in CBP compared with freestall barns (Barberg et al., 2007b; Fulwider et al., 2007; Lobeck et al., 2011). Barberg et al. (2007b), Black et al. (2013), Lobeck et al. (2011), and Petzen et al. (2009) witnessed decreased lameness in cows housed in CBP compared with freestall systems. Eckelkamp et al. (2016a) did not report a decrease in lameness or hock lesions, but no differences were detected between CBP and sand freestall barns.

\section{ROBOTIC MILKING}

The newest addition to housing systems are automatic milking systems (AMS; Hulsen and Rodenburg, 2008). The first AMS was installed in the Netherlands in 1992, increasing to over 8,000 worldwide in 2009 (Svennersten-Sjaunja and Pettersson, 2008; de Koning, 2010). Although AMS reduce the manual labor attached to traditional milk parlors, AMS require cows to voluntarily come to be milked (Hulsen and Rodenburg, 2008; Jacobs and Siegford, 2012). Consequently, barns must be designed to encourage cows to visit the AMS voluntarily or by guided flow (Jacobs and Siegford, 2012). In the mid-2000s, barns began to be designed around AMS systems instead of AMS being added to an existing freestall barn. To encourage visits by cows to an AMS, a barn must be designed for excellent cow traffic. Cow traffic is governed by a series of gates (or pathways in the absence of gates) that guide cows throughout the barn (Jacobs and Siegford, 2012).

Free-flow systems allow cows to move freely between the AMS, feed area, and resting area (Melin et al., 2006; Tremblay et al., 2016). Forced, one-way, or guided flow leads cows to be milked at the AMS before eating at the feed alley (Jacobs and Siegford, 2012). This system can be adjusted with selection gates to only guide cows over the time allotted between milking to the AMS (Melin et al., 2006). Building this system may reduce the number of cows that need to be fetched, but may also reduce eating time and resting time. However, conflicting reports exist on the effect of guided flow on eating time and lying time (Jacobs and Siegford, 2012). A recent paper associated greater milk yield with freeflow systems compared with forced flow (Tremblay et al., 2016). Ipema (1997) suggested that the choice of free or forced flow should be made based on productivity, lying behavior, and individual cow reactions to the system.

Designing facilities to improve cow comfort (e.g., resting area, walkways, cleanliness) will improve AMS use. Lame cows will require more "fetches" than their nonlame counterparts (Ipema et al., 1987; Ipema, 1997). When facilities are designed to promote cow flow with positive enforcement of concentrates fed in the AMS, as few as $0.8 \%$ of milkings/cow will require fetching (Ipema, 1997). Placing selection units (gates guiding cows to the AMS or the feed alley) in the passage from the resting area to the feed alley can decrease unsuccessful visits to an AMS system. An unsuccessful visit would be one when a cow has been milked too recently to be milked again and is entering the robot for another reason. Although the time lag from this may seem small, on a costly investment such as an AMS, having only viable cows enter increases productivity. Placing the exit of the AMS near the feed alley will capitalize on cows' drive to eat following a milking event (MetzStefanowska et al., 1993; Halachmi et al., 2000).

Providing enough space for cows to comfortably enter and exit the AMS is important. Free-flow lanes should range between 4 and $7 \mathrm{~m}$ wide. Within a holding pen in guided flow, allowing animals $1.3 \mathrm{~m}^{2}$ per cow (the number the pen is intended to hold) and $33 \mathrm{~m}^{2}$ of free space around the selection unit is preferable (Ipema, 1997). Adding automatic alley scrapers in freestall barns can also improve cow hygiene (Buitink, 1991; Ipema, 1997).

In the early 2000s, Halachmi (2000) suggested changes in AMS design based on a simulation model. Using process orientation, Halachmi (2000) determined that a 40-cow herd used space more efficiently in a robotic milking barn than what is typically seen in a freestall barn. To maximize efficiency, cows were provided with 35 stalls and 12 feed spaces (equivalent to recommended space per cow). With concentrate supplied at the AMS, and in the case of Halachmi (2000), 2 additional concentrate feeders, less area was required to devote to a partially mixed ration. Based on time management and allowing cows to decide their own schedule, barn design may be more successful through techniques described in Halachmi et al. (2000) and Halachmi (2000).

\section{FUTURE DIRECTIONS}

Freestall and cubicle housing systems are the primary housing system for lactating dairy cattle in many parts of the world. Early freestall barns lacked features that maximized cow comfort. Today, modern freestall barns are generally cow-centered with a large focus on cow comfort. Among freestall barns, the sand-bedded freestall barn is often promoted as the ideal system. However, after decades of housing cows in freestalls, limitations remain. Lameness levels remain high in many freestall barns, and manure handling is challenging. Further, as the science of animal behavior grows and consumers place more pressure on dairy farms, new questions arise around natural behavior within freestalls. Should freestall barns be the housing of the future? Would other housing options promote more natural behaviors and remove some of the limitations of 
freestall barns? What alternative systems hold promise? The term "freewalk housing" has been used to describe housing systems that provide animals the opportunity to walk more freely within the barn, often in combination with grazing access. Compost bedded-pack barns and cow gardens are 2 examples of freewalk housing. A compost bedded-pack barn consists of a large, open resting area, usually bedded with sawdust or dry, fine wood shavings. Bedding material is composted in place, along with manure, when mechanically stirred on a regular basis. Producers report reduced incidence of lameness and improved hoof health resulting from greater lying times and a softer, drier surface for standing. The cow garden system has a multi-layer, semi-permeable floor. Manure is removed by robotic scrapers, and trees and plants are planted within the barn. Questions remain about the suitability of these facilities.

Advancements in monitoring technologies and materials science may provide new refinements to dairy cattle housing. Real-time location systems may enable targeted cooling based on presence or absence of cows in a particular part of the barn. Physiological and behavioral technologies may be incorporated into feedback loops to control whole or micro-environments within dairy facilities. Innovations in materials science may lead to better solutions for cow resting surfaces or beddings. As the industry has grasped the importance of cow comfort in optimizing production, health, and well-being, more solutions will be sought to continue to improve lactating cow housing environments.

In evaluation of alternative systems, a systems approach must be applied that addresses animal behavior, economics, and environmental sustainability. The dairy farm is a complex system, and lactating cow housing plays an important role within that system. No one factor can or should dictate what type of housing is chosen. Rather, the choice is a balance of many internal and external factors. Dairy cattle housing of the future will likely reflect continued emphasis on consumer demands, animal behavior, and environmental impact. It is difficult to predict what future housing systems will be developed and most widely adopted. However, when one considers how dramatically housing systems have changed in the last 100 years, we should expect similar, if not more rapid, progress in the next 100 years.

\section{REFERENCES}

Albino, R. L., J. L. Taraba, M. I. Marcondes, E. A. Eckelkamp, and J. M. Bewley. 2017. Comparison of bacterial populations in bedding material, on teat ends, and in milk of cows housed in compost bedded pack barns. Anim. Prod. Sci. https://doi.org/10.1071/ AN16308.

Allen, D. 2007. The impact of housing on mastitis. Pages 35-41 in Proc. British Mastitis Conf., Warwickshire, UK.
Anderson, N. 2008a. Dairy cow comfort free-stall dimensions. Ontario Ministry of Agriculture, Food, and Rural Affairs, Guelph, ON, Canada. Accessed July 24, 2014. http://www.omafra.gov.on.ca/ english/livestock/dairy/facts/freestaldim.htm.

Anderson, N. 2008b. Tie-stall dimensions. Ministry of Agriculture, Food and Rural Affairs, Guelph, ON, Canada.

Anderson, N. 2014. Dairy cow comfort tie-stall dimensions. Ontario Ministry of Agriculture, Food and Rural Affairs, Guelph, ON, Canada.

Barberg, A. E., M. I. Endres, and K. A. Janni. 2007a. Compost dairy barns in Minnesota: A descriptive study. Appl. Eng. Agric. 23:231238.

Barberg, A. E., M. I. Endres, J. A. Salfer, and J. K. Reneau. 2007b. Performance and welfare of dairy cows in an alternative housing system in Minnesota. J. Dairy Sci. 90:1575-1583.

Batchelder, M. S., inventor. 1911. Cow-stall. M. S. Batchelder, assignee. United States Pat. No. US1009714A.

Benson, A. F. 2012. Consider deep pack barns for cow comfort and manure management. Cornell University, Ithaca, NY, Accessed February 17, 2014. http://smallfarms.cornell.edu/2012/04/20/consider -deep-pack-barns-for-cow-comfort-and-manure-management/.

Berg, V. R., inventor. 1964. Tie-stall for cattle. United States Pat. No. US3123051A.

Bewley, J. M., J. L. Taraba, G. B. Day, and R. A. Black. 2012. Compost bedded pack barn design features and management considerations. Cooperative Extension Publ. ID-206, Cooperative Extension Service, University of Kentucky College of Agriculture, Lexington.

Bewley, J. M., J. L. Taraba, D. McFarland, P. Garrett, R. Graves, B. Holmes, D. Kammel, J. Porter, J. Tyson, S. Weeks, and P. Wright. 2013. Guidelines for managing compost bedded-pack barns. The Dairy Practices Council, Accessed June 4, 2014. https://www .dairypc.org/catalog/guidelines-for-managing-compost-bedded -pack-barns.

Bickert, W. G. 1999. Building and remodeling freestall housing for cow comfort. Adv. Dairy Technol. 11:335-342.

Bickert, W. G., B. Holmes, K. A. Janni, D. Kammel, R. Stowell, and J. M. Zulovich. 2000. Dairy freestall housing and equipment. Pages 27-45 in Designing Facilities for the Milking Herd. 7th ed., MidWest Plan Service, Iowa State University, Ames.

Bickert, W. G., and R. G. Light. 1982. Housing systems. J. Dairy Sci. 65:502-508.

Bielfeldt, J. C., R. Badertscher, K. H. Tolle, and J. Krieter. 2005. Risk factors influencing lameness and claw disorders in dairy cows. Livest. Prod. Sci. 95:265-271.

Bjerg, B. S., and I. C. Klaas. 2014. Water and ammonia evaporation in a compost bedded pack dairy barn with under floor aeration. Pages 1-7 in Proc. ASABE and Canadian Society for Bioengineering/ Société Canadienne de Génie Agroalimentaire et de Bioingénierie Annual International Meeting, Montreal, QC, Canada.

Black, R. A., J. L. Taraba, G. B. Day, F. A. Damasceno, and J. M. Bewley. 2013. Compost bedded pack dairy barn management, performance, and producer satisfaction. J. Dairy Sci. 96:8060-8074.

Black, R. A., J. L. Taraba, G. B. Day, F. A. Damasceno, M. C. Newman, K. A. Akers, C. L. Wood, K. J. McQuerry, and J. M. Bewley. 2014. The relationship between compost bedded pack performance, management, and bacterial counts. J. Dairy Sci. 97:2669-2679.

Brewer, W. H., inventor. 1890. Stable-floor. United States Pat. No. US427547A.

Briggs, D. G. 1994. Forest products measurements and conversion factors: With special emphasis on the US Pacific Northwest. Chapter 7: Chips, sawdust, planer shavings, bark, and hog fuel. College of Forest Resources, Institute of Forest Resources, Publ. AR-10, University of Washington, Seattle.

Buitink, W. J. 1991. Onderzoek naar technieken ter verbetering van de stalhygiene. IMAG-DLO Report 91-2. Wageningen, the Netherlands.

Buli, T. A., S. Elwes, J. Geerets, and P. Schildmeijer. 2010. Sand: A review of its use in housed dairy cows. Vetvice BV, Bergen op Zoom, the Netherlands. http://www.vetvice.com/upload/files/ Stallenbouwadvies/100325_Sand_a_review.pdf. 
Cook, N. B. 2010. Troubleshooting and evaluating cow comfort and free stall design on dairy operations. University of Wisconsin-Madison, Madison, WI, Accessed July 24, 2014. http://www.vetmed.wisc.edu/dms/fapm/publicats/proceeds/ troubleshootingcowcomfortandfreestalls.pdf.

Cow-Welfare. 2017. Free stall that boosts cow comfort. Cow-Welfare A/S, Haderslev, Denmark. https://www.cow-welfare.com/en/free -stall-boosts-cow-comfort/.

Damasceno, F. A. 2012. Compost bedded pack barns system and computational simulation of airflow through naturally ventilated reduced model. PhD Diss. Universidade Federal de Viçosa, Viçosa, Minas Gerais, Brazil.

de Koning, K. 2010. Automatic milking-Common practice on dairy farms. Pages V59-V63 in Proc. 2nd North Am. Conf. Robotic Milking, Toronto, Canada. Precision Dairy Operators, Elora, ON, Canada.

Dechow, C. D., E. A. Smith, and R. C. Goodling. 2011. The effect of management system on mortality and other wlefare indicators in Pennsylvania dairy herds. Anim. Welf. 20:145-158.

Douridas, A. 2012. Economic considerations for composting dairy barns. In Proceedings of Multi-State Workshop: Composting Bedded Pack Dairy Barns. The Ohio State University Extension, Wooster, Dec. 5, 2012. Accessed Aug. 31, 2017. https://airquality .osu.edu/sites/airquality/files/imce/4_Douridas_0.pdf.

Eckelkamp, E. A. 2014. Compost bedded pack barns for dairy cattle: Bedding performance and mastitis as compared to sand freestalls. Pages 175-222 in Theses and Dissertations-Animal and Food Sciences, University of Kentucky, Lexington.

Eckelkamp, E. A., C. N. Gravatte, C. O. Coombs, and J. M. Bewley. 2014. Case study: Characterization of lying behavior in dairy cows transitioning from a freestall barn with pasture access to a compost bedded pack barn without pasture access. Prof. Anim. Sci. 30:109-113.

Eckelkamp, E. A., J. L. Taraba, K. A. Akers, R. J. Harmon, and J. M. Bewley. 2016a. Sand bedded freestall and compost bedded pack effects on cow hygiene, locomotion, and mastitis indicators. Livest. Sci. 190:48-57.

Eckelkamp, E. A., J. L. Taraba, K. A. Akers, R. J. Harmon, and J. M. Bewley. 2016b. Understanding compost bedded pack barns: Interactions among environmental factors, bedding characteristics, and udder health. Livest. Sci. 190:35-42.

Endres, M. I., and K. A. Janni. 2007. Compost bedded pack barns for dairy cattle. University of Minnesota Dairy Extension. Accessed Aug. 31, 2017. https://www.extension.umn.edu/agriculture/ dairy/facilities/compost-bedded-pack-barns/.

Fairchild, T. P., B. J. McArthur, J. H. Moore, and W. E. Hylton. 1982. Coliform counts in various bedding materials. J. Dairy Sci. 65:1029-1035.

Ferrari, P., and G. Moscatelli. 2009. Manure management, hygienic conditions and greenhouse gas emissions in dairy farms using recycled manure solids as bedding for cows. Pages 131-138 in Proc. European Forum Livestock Housing for the Future, Lille, France. Institut de l'Élevage, Paris, France.

Fregonesi, J. A., and J. D. Leaver. 2001. Behaviour, performance and health indicators of welfare for dairy cows housed in strawyard or cubicle systems. Livest. Prod. Sci. 68:205-216.

Fregonesi, J. A., and J. D. Leaver. 2002. Influence of space allowance and milk yield level on behaviour, performance and health of dairy cows housed in strawyard and cubicle systems. Livest. Prod. Sci. $78: 245-257$.

Fregonesi, J. A., M. A. G. von Keyserlingk, and D. M. Weary. 2009. Cow preference and usage of free stalls compared with an open pack area. J. Dairy Sci. 92:5497-5502.

Fulwider, W. K., T. Grandin, D. J. Garrick, T. E. Engle, W. D. Lamm, N. L. Dalsted, and B. E. Rollin. 2007. Influence of free-stall base on tarsal joint lesions and hygiene in dairy cows. J. Dairy Sci. 90:3559-3566.

Galama, P. 2011. Prospects for bedded pack barns for dairy cattle. Wageningen UR Livestock Research, Wageningen, the Netherlands.

Gibbs, J., inventor. 1887. Cattle-stall. United States Pat. No. US369333A.
Graves, R. E. 2015. Penn State housing plans for dairy tie stall shelters. D. F. McFarland, ed. Penn State Cooperative Extension.

Graves, R. E. 2017. Natural ventilation for dairy tie stall barns. Penn State Extension. Accessed Aug. 31, 2017. https://extension.psu .edu/natural-ventilation-for-dairy-tie-stall-barns.

Halachmi, I. 2000. Designing the optimal robotic milking barn, Part 2: Behaviour-based simulation. J. Agric. Eng. Res. 77:67-79.

Halachmi, I., J. H. M. Metz, E. Maltz, A. A. Dijkhuizen, and L. Speelman. 2000. Designing the optimal robotic milking barn, Part 1: Quantifying facility usage. J. Agric. Eng. Res. 76:37-49.

Hatch, G. W., inventor. 1850. Stanchion for cattle. United States Pat. No. US7524A.

Hibbs, E. G., and D. D. Miller, inventors. 1932. Stall construction. Ney Mfg. Co., assignee. United States Pat. No. US1839313A.

Hogan, J. S., K. L. Smith, K. H. Hoblet, D. A. Todhunter, P. S. Schoenberger, W. D. Hueston, D. E. Pritchard, G. L. Bowman, L. E. Heider, B. L. Brockett, and H. R. Conrad. 1989. Bacterial counts in bedding materials used on nine commercial dairies. J. Dairy Sci. 72:250-258.

Hulsen, J., and J. Rodenburg. 2008. Robotic Milking. Roodbont Publ., Zutphen, the Netherlands.

Huse, W. E., inventor. 1880. Cattle-stanchion. United States Pat. No. US227256A.

Ipema, A. H. 1997. Integration of robotic milking in dairy housing systems: Review of cow traffic and milking capacity aspects. Comput. Electron. Agric. 17:79-94.

Ipema, A. H., E. Benders, and W. Rossing. 1987. Effect of more frequent daily milking on production and health of dairy cattle. Pages 283-293 in Proc. 3rd Symp. Autom. Dairying, Instituut voor Mechanisatie, Arbeid en Gebouwen, Wageningen, the Netherlands.

Jacobs, J. A., and J. M. Siegford. 2012. Invited review: The impact of automatic milking systems on dairy cow management, behavior, health, and welfare. J. Dairy Sci. 95:2227-2247.

Janni, K. A., M. I. Endres, J. K. Reneau, and W. W. Schoper. 2006. Compost dairy barn layout and management recommendations. Pages 97-102 in ASAE Annual Meeting Vol. 23(1). American Society of Agricultural and Biological Engineers, Boston, MA.

Jost, W. A., inventor. 1930. Cow trainer. W. A. Jost, assignee. United States Pat. No. US1746770A.

Kammel, D. W. 2005. Design and maintenance of a bedded pen (pack) housing system. University of Wisconsin Extension, Madison.

Klaas, I. C., B. Bjerg, S. Friedmann, and D. Bar. 2010. Cultivated barns for dairy cows-An option to promote cattle welfare and environmental protection in Denmark? Dan. Vet. 93:20-29.

Konggaard, S. P. 1977. Comparison between conventional tie-barn and loose housing systems with respect to milk production, feed conversion and reproductive performance of dairy cows. Livest. Prod. Sci. 4:69-77.

LeBlanc, L., and D. Anderson. 2013. Waste wallboard and wood fiber for use as an alternative dairy bedding material. LP Consulting Limited, Mount Uniacke, NS, Canada.

Livesey, C. T., T. Harrington, A. M. Johnston, S. A. May, and J. A. Metcalf. 1998. The effect of diet and housing on the development of sole haemorrhages, white line haemorrhages and heel erosions in Holstein heifers. Anim. Sci. 67:9-16.

Lobeck, K. M., M. I. Endres, E. M. Shane, S. M. Godden, and J. Fetrow. 2011. Animal welfare in cross-ventilated, compost bedded pack, and naturally ventilated dairy barns in the upper Midwest. J. Dairy Sci. 94:5469-5479.

Main, A. 2013. The effects of a gel mat stall surface on the lying behavior of dairy cattle. Pages 34-70 in Theses and Dissertations-Population Medicine. The University of Guelph, Guelph, ON, Canada.

McCartney, J. S., inventor. 1887. Cattle-stanchion. United States Pat. No. US363902A.

Melin, M., G. G. N. Hermans, G. Pettersson, and H. Wiktorsson. 2006. Cow traffic in relation to social rank and motivation of cows in an automatic milking system with control gates and an open waiting area. Appl. Anim. Behav. Sci. 96:201-214.

Metz-Stefanowska, J., C. C. Ketelaar-de Lauwere, and A. H. Ipema. 1993. Mogelijkheden om het koeverkeer te beinvloeden ten behoeve 
van het automatisch melken (Influencing cow traffic for the purpose of automatic milking). IMAG-DLO Report 92-13, Wageningen, the Netherlands.

Newman, L. E., and J. Kowalski. 1973. Fresh sawdust bedding-A possible source of Klebsiella organisms. Am. J. Vet. Res. 34:979-980.

Norring, M., E. Manninen, A. M. de Passillé, J. Rushen, L. Munksgaard, and H. Saloniemi. 2008. Effects of sand and straw bedding on the lying behavior, cleanliness, and hoof and hock injuries of dairy cows. J. Dairy Sci. 91:570-576.

NYSCHAP. 2002. Bedding materials and udder health. Mastitis Module Fact Sheet. New York State Cattle Health Assurance Program, Accessed May 4, 2014. http://nyschap.vet.cornell.edu/module/ mastitis/section1/BeddingMaterialsUdderHealth.pdf.

Petzen, J., C. Wolfanger, J. Bonhotal, M. Schwarz, T. Terry, and N. Youngers. 2009. Case study: Eagleview compost dairy barn. Cornell Cooperative Extension of Wyoming County, Warsaw, NY, Accessed Aug. 4, 2014. http://counties.cce.cornell.edu/wyoming.

Phillips, C. J. C., and S. A. Schofield. 1994. The effect of cubicle and straw yard housing on the behaviour, production and hoof health of dairy cows. Anim. Welf. 3:37-44.

Rodenburg, J. 2000. Sand bedding for dairy cows has benefits and costs. Ontario Ministry of Agriculture, Food, and Rural Affairs, Accessed July 24, 2014. http://www.omafra.gov.on.ca/english/ livestock/dairy/facts/info_sandbed.htm.

Rousseau, V., S. Desjardins, and L. Rousseau, inventors. 1999. Cow training device for cow stalls. Rovibec Inc., original assignee. United States Pat. No. US6176203B1.

Schreiner, D. A., and P. L. Ruegg. 2003. Relationship between udder and leg hygiene scores and subclinical mastitis. J. Dairy Sci. $86: 3460-3465$.

Shane, E. M., M. I. Endres, and K. A. Janni. 2010. Alternative bedding materials for compost bedded pack barns in Minnesota: A descriptive study. Appl. Eng. Agric. 26:465-473.

Sheils, A., inventor. 1894. Vacuum regulating apparatus for milking machines. US Pat. No. US513624A.

Somers, J. G. C. J., K. Frankena, E. N. Noordhuizen-Stassen, and J. H. M. Metz. 2003. Prevalence of claw disorders in Dutch dairy cows exposed to several floor systems. J. Dairy Sci. 86:2082-2093.

Stowell, R. R., and S. Inglis. 2000. Sand for bedding. Pages 226-234 in Proc. Dairy Housing and Equipment Systems: Managing and Planning for Profitability. NRAES-129. Natural Resource, Agriculture and Engineering Service, Ithaca, NY.

Svennersten-Sjaunja, K. M., and G. Pettersson. 2008. Pros and cons of automatic milking in Europe. J. Anim. Sci. 86(Suppl.):37-46.
Thurgood, J. M., C. M. Comer, D. J. Flaherty, and M. Kiraly. 2009 Bedded pack management system case study. Pages 184-188 in Proc. 5th National Small Farm Conference, Springfield, IL. Accessed Aug. 31, 2017. http://conferences.illinois.edu/resources/ 20033/Proceedings_8-12-13.pdf.

Treangen, O. M., inventor. 1966. Electric animal trainer. United States Pat. No. US3370570A.

Tremblay, M., J. P. Hess, B. M. Christenson, K. K. McIntyre, B. Smink, A. J. van der Kamp, L. G. de Jong, and D. Döpfer. 2016. Factors associated with increased milk production for automatic milking systems. J. Dairy Sci. 99:3824-3837.

Tucker, C. B., D. M. Weary, and D. Fraser. 2004. Free-stall dimensions: Effects on preference and stall usage. J. Dairy Sci. 87:1208-1216.

Tucker, C. B., D. M. Weary, and D. Fraser. 2005. Influence of neck-rail placement on free-stall preference, use, and cleanliness. J. Dairy Sci. 88:2730-2737.

Tucker, C. B., G. Zdanowicz, and D. M. Weary. 2006. Brisket boards reduce freestall use. J. Dairy Sci. 89:2603-2607.

Tyson, J. T., D. F. McFarland, and R. E. Graves. 2014. Tunnel ventilation for tie stall dairy barns. Penn State Extension. Accessed Aug. 31, 2017. https://extension.psu.edu/tunnel-ventilation-for-tie -stall-dairy-barns.

van Gastelen, S., B. Westerlaan, D. J. Houwers, and F. J. C. M. van Eerdenburg. 2011. A study on cow comfort and risk for lameness and mastitis in relation to different types of bedding materials. J. Dairy Sci. 94:4878-4888.

Vokey, F. J., C. L. Guard, H. N. Erb, and D. M. Galton. 2001. Effects of alley and stall surfaces on indices of claw and leg health in dairy cattle housed in a free-stall barn. J. Dairy Sci. 84:2686-2699.

Wagner, P. E. 2002. Bedded pack shelters. Lancaster Farming 47:36.

Webster, A. J. F. 2001. Effects of housing and two forage diets on the development of claw horn lesions in dairy cows at first calving and in first lactation. Vet. J. 162:56-65.

Witt, W., inventor. 1897. Cow tie. United States Pat. No. US589914A.

Zhao, L., H. Keener, M. Wicks, M. Brugger, S. Wang, J. Rausch A. Meddles, M. Klingman, R. Manuzon, and J. Upadhyay. 2012 Indoor environment of compost bedded dairy barns in Ohio. In Proceedings of Multi-State Workshop: Composting Bedded Pack Dairy Barns. The Ohio State University Extension, Wooster, Dec. 5, 2012. Accessed Aug. 31, 2017. https://airquality.osu.edu/sites/ airquality/files/imce/8_Zhao_0.pdf.

Zurbrigg, K., D. Kelton, N. Anderson, and S. Millman. 2005. Tie-stall design and its relationship to lameness, injury, and cleanliness on 317 Ontario dairy farms. J. Dairy Sci. 88:3201-3210. 


\section{APPENDIX}

Table A1. Timeline of developments in lactating dairy cattle housing

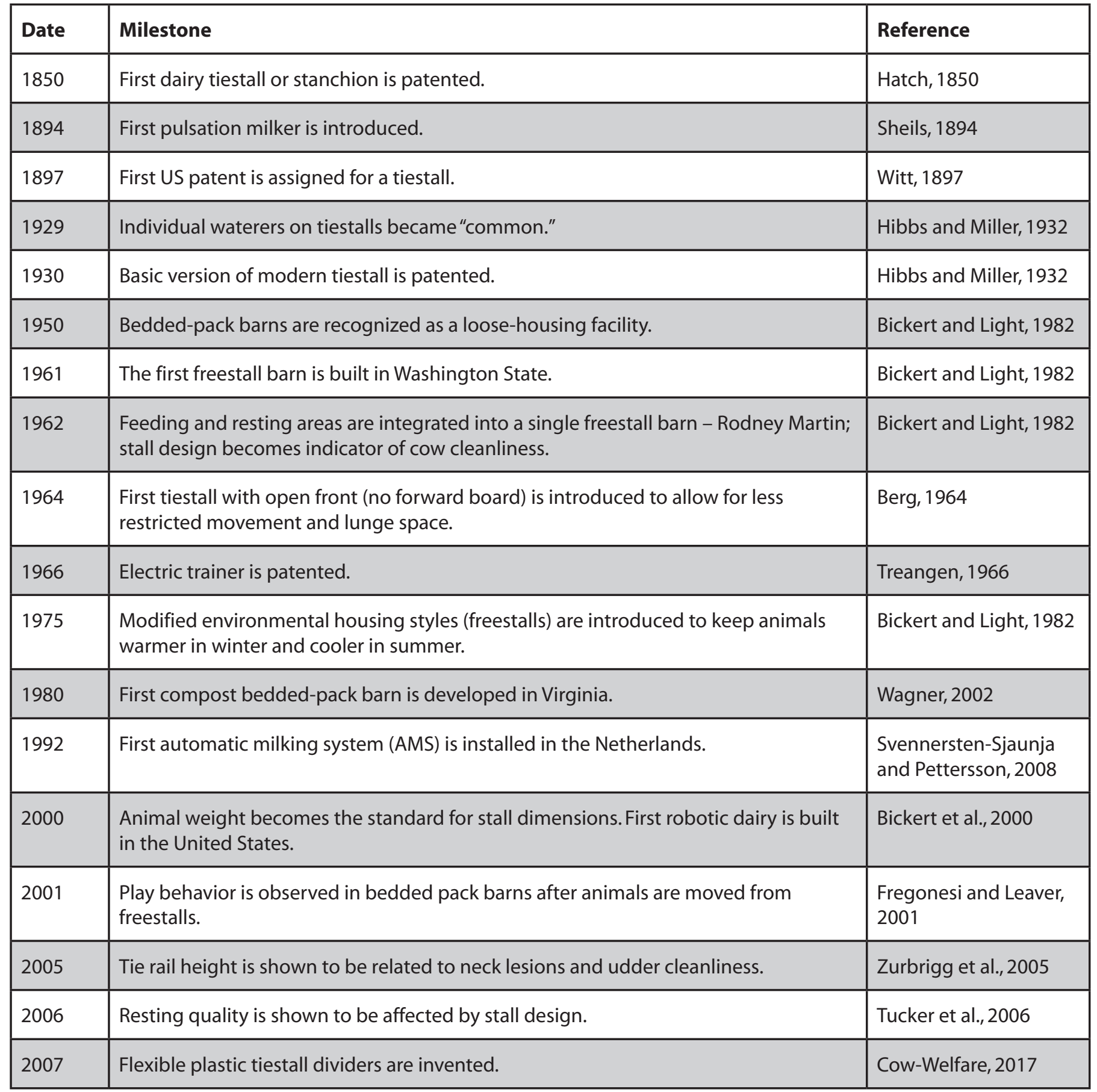

